\title{
HIGHLIGHTS
}

HIGHLIGHT ADVISORS

\section{DAVID BLAUSTEIN}

THE GALLEON GROUP, NEW YORK, NY, USA

\section{ERIK DE CLERCQ}

KATHOLIEKE UNIVERSITEIT LEUVEN, BELGIUM

\section{RODERICK FLOWER}

WILLIAM HARVEY RESEARCH

INSTITUTE, QMW, LONDON, UK

\section{F. PETER GUENGERICH}

VANDERBILT UNIVERSITY

NASHVILLE, TN, USA

\section{FRANZ HEFTI}

MERCK RESEARCH

LABORATORIES, SAN DIEGO,

CA, USA

\section{JOAN HELLER BROWN}

UNIVERSITY OF CALIFORNIA

SAN DIEGO, CA, USA

MADS KROGSGAARD

\section{THOMSEN}

NOVO NORDISK, BAGSVAERD,

DENMARK

\section{HUGO KUBINYI}

UNIVERSITY OF HEIDELBERG, GERMANY

\section{JULIO LICINIO}

UNIVERSITY OF CALIFORNIA LOS ANGELES, CA, USA

\section{CHRISTOPHER LIPINSKI}

PFIZER GLOBAL RESEARCH AND DEVELOPMENT, GROTON,

CT, USA

\section{LESLIE MEYER-LEON}

IP LEGAL STRATEGIES GROUP, OSTERVILLE, MA, USA

\section{TOMI SAWYER}

ARIAD PHARMACEUTICALS, CAMBRIDGE, MA, USA

\section{GEORGE SCHLICH}

MATHYS \& SQUIRE, LONDON, UK

\section{JANET WOODCOCK}

CENTER FOR DRUG

EVALUATION AND RESEARCH, WASHINGTON, MD, USA

\section{OBESITY}

\section{PPAR $\gamma 2$ piles on the pounds}

Weakness for snacks. Unused gym membership. Taking the lift, not the stairs. All could be blamed for a few extra inches on our waistlines. Now, as two papers in Genes \& Development reveal, a key culprit - albeit at the molecular level — is the $\gamma 2$ isoform of the peroxisome proliferator-activated receptor (PPAR $\gamma 2)$.

PPAR $\gamma$, a nuclear hormone receptor that regulates gene expression, has received much attention in recent years, in part owing to its emerging link with fat-cell development, or adipogenesis. PPAR $\gamma$ and another transcription factor, $\mathrm{C} / \mathrm{EBP} \alpha$, are both known to be crucial in adipogenesis, but their exact role has been hard to establish, as they positively regulate each other's expression. Although previous studies have shown that addition of PPAR $\gamma$ can induce adipogenesis in the absence of $\mathrm{C} / \mathrm{EBP} \alpha$, it was not known whether the converse was true. As described in the first of the two papers, researchers in Bruce Spiegelman's lab have clarified this issue by generating a cell line lacking PPAR $\gamma$. They used this cell line to show that $\mathrm{C} / \mathrm{EBP} \alpha$ has no ability to promote adipogenesis in the absence of PPAR $\gamma$, thus indicating that PPAR $\gamma$ is the key regulator in a single adipogenic pathway, rather than PPAR $\gamma$ and C/EBP $\alpha$ each being able to act independently to promote adipogenesis.

However, PPAR $\gamma$ has two main isoforms, PPAR $\gamma 1$ and PPAR $\gamma 2$. Although their expression patterns differ - PPAR $\gamma 1$ is expressed in various cells including fat cells, whereas PPAR 2 expression is fat-cell specific - the two isoforms are expressed at comparable levels in fat cells, so their relative importance to adipogenesis was not clear. This question was addressed by Heidi Camp and colleagues in the second paper. Using transcriptional repressors engineered to bind specifically to the PPAR $\gamma$ gene via novel zinc fingers, they created cells lacking PPAR $\gamma$, which, as in previous work, were unable to develop into fat cells. Then, by selectively restoring the expression of either PPAR $\gamma 1$ or PPAR $\gamma 2$ using retroviruses, they showed that only PPAR $\gamma 2$ could reactivate adipogenesis.

These advances in our understanding of adipogenesis further the hope that rational manipulation of this process could be a therapeutic strategy for combating obesity. However, in animal models, direct and powerful inhibition of adipogenesis leads to lipodystrophy, indicating that a more measured approach - for example, pharmacological reduction of PPAR $\gamma$ in a

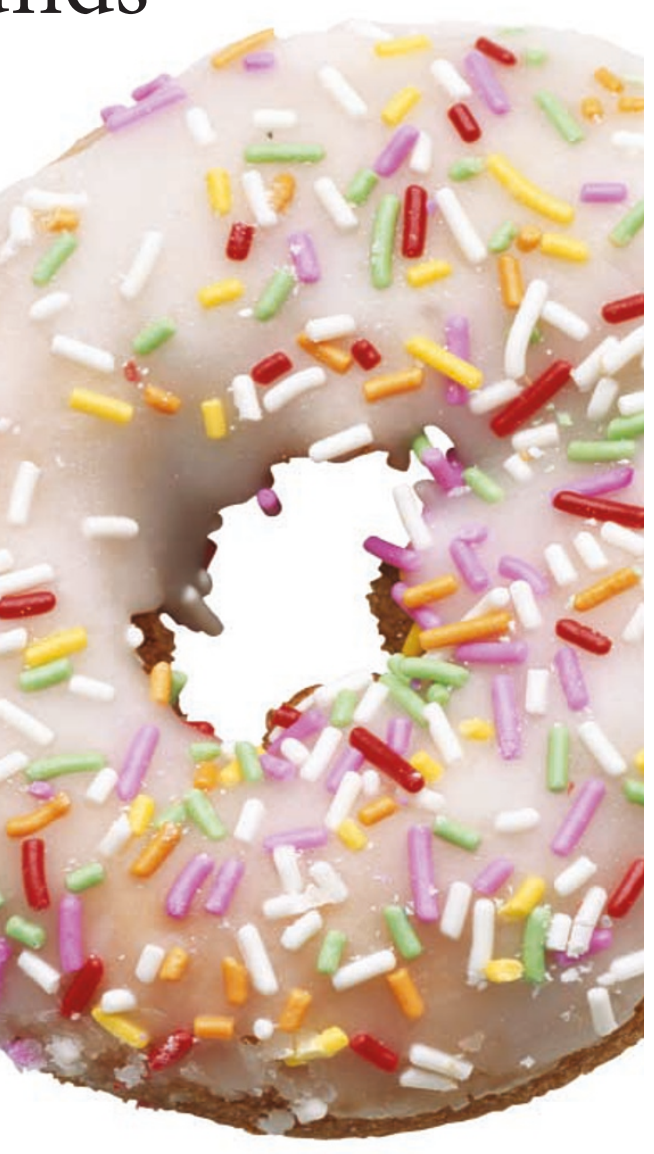

controlled manner — is likely to be a necessity.

Peter Kirkpatrick

(Q) References and links ORIGINAL RESEARCH PAPERS Rosen, E. D. etal. $\mathrm{C} / \mathrm{EBP} \alpha$ induces adipogenesis through PPARY: a unified pathway. Genes Dev 16, 22-26 (2002) . transcription factors: exogenous PPARy 2 but not PPARy 1 reactivates adipogenesis. Genes Dev. 16 27-32 (2002)

FURTHER READING Rosen, E. D. et al. PPARy is required for the differentiation of adipose tissue in vivo and in vitro. Mol. Cell 4, 611-617 (1999) 